\title{
Growth hormone response in fetal alcohol syndrome
}

\author{
WAH JUN TZE, HENRY G. FRIESEN, and PATRICK M. MacLEOD \\ From the Departments of Pediatrics and Medical Genetics, University of British Columbia, and Department of \\ Physiology, University of Manitoba, Canada
}

\begin{abstract}
Tze, W. J., Friesen, H. G., and MacLeod, P. M. (1976). Archives of Disease in Childhood, 51, 703. Growth hormone response in fetal alcohol syndrome. In the fetal alcohol syndrome (FAS) there is severe physical growth retardation both prenatally and postnatally. Secretion of growth hormone (GH) after insulin-induced hypoglycaemia and arginine infusion was analysed in 5 cases of FAS to find out whether changes in GH secretion might account for the abnormal growth pattern. Results showed a normal or slight hyper-response of $\mathrm{GH}$ up to $150 \mathrm{ng} / \mathrm{ml}$, and normal somatomedin activity in those blood samples with high GH level. It was concluded that the growth retardation in FAS is not caused by GH or somatomedin deficiencies.
\end{abstract}

The fetal alcohol syndrome (FAS) in the offspring of mothers who had consumed excessive quantities of alcohol during their pregnancies was described in 1973 by Jones and Smith and Jones et al. The clinical features include low birthweight for gestational age, small head circumference and palpebral fissures, delayed behavioural development, postnatal growth deficiency, and multiple minor abnormalities. Postnatally the growth failure persists, but the growth hormone status in the patients has not been defined. We have examined this aspect in 5 cases of FAS.

\section{Subjects and methods}

The criteria for alcoholism established by the Criteria Committee, National Council on Alcoholism (1972) applied to the mothers of the 5 patients. The 5 children (including two sibs) were referred to the Endocrine Clinic, Vancouver Children's Hospital, for investigation of growth failure. All were residing in good foster homes, having been placed there soon after birth, and received good care and nutritional intake.

Human growth hormone (HGH) secretion was assessed after insulin-induced hypoglycaemia (0-05 units $/ \mathrm{kg}$ ) and subsequently arginine infusion on a separate day $(0 \cdot 5 / \mathrm{kg})$. The test procedure was performed under standard conditions after overnight fasting. Blood samples at $-30,0,15,30,45,60,90$, and 120 minutes after insulin load, and $-30,0,30$, and 60 minutes after arginine infusion were obtained through an indwelling venous catheter. Blood glucose was determined by the glucose oxidase method. GH was measured by a double antibody radioimmunoassay.

The serum samples with raised immunoreactive

Received 29 January 1976. growth hormone of $150 \mathrm{ng} / \mathrm{ml}$ and $147 \mathrm{ng} / \mathrm{ml}$ in Cases 2 and 3 respectively were assessed for somatomedin activity (by Dr. M. Bala, University of Calgary), using rabbit cartilage (Bala, Hankins, and Smith, 1975). The concentrations of somatomedin in Cases 2 and 3 were compared with the concentration found in a serum pool obtained from normal subjects.

\section{Results}

Table I shows the clinical details in the 5 children and Figs. 1 and 2 show the height and weight. Physical growth was markedly impaired and was apparent in very early life. No catch-up growth was observed. Normal laboratory results were attained including serum levels of electrolytes, calcium, inorganic phosphate, cholesterol, thyroxine, cortisol, and urinary 17-ketogenic steroid levels with metyrapone test. Karyotypes and the electroencephalograms were normal. Skull $x$-ray showed head size more than 2 SD below the mean; and bone age was similarly more than 2 SD behind the chronological age in all 5 cases. The pneumoencephalogram performed in one patient (Case 1) was normal.

Immunoreactive growth hormone levels are shown in Table II. 3 of the 5 patients showed high fasting GH serum levels. 3 of the 5 children showed raised growth hormone after insulin load. The hypoglycaemia induced by the insulin was adequate with at least a $50 \%$ reduction from the baseline level. After arginine infusion 3 of 5 patients showed raised GH levels at the end of a 30-minute period relative to the control group (Pozsonyi and Friesen, 1971). 
TABE

Clinical features of 5 childen

\begin{tabular}{|c|c|c|c|c|c|c|}
\hline $\begin{array}{l}\text { Case } \\
\text { no. * }\end{array}$ & $\begin{array}{l}\text { Maternal age } \\
\text { at birth of child } \\
\text { (year) }\end{array}$ & $\begin{array}{c}\text { Age of child } \\
\text { on admission } \\
\text { (year) }\end{array}$ & Sex & $\begin{array}{c}\text { Gestational } \\
\text { age } \\
\text { (w) }\end{array}$ & $\begin{array}{c}\text { Birthweight } \\
\text { (g) }\end{array}$ & 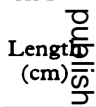 \\
\hline $\begin{array}{l}1 \\
2 \\
3 \\
4 \\
5\end{array}$ & $\begin{array}{l}37 \\
32 \\
29 \\
24 \\
22\end{array}$ & $\begin{array}{l}0 \cdot 4 \\
1 \cdot 25 \\
2 \cdot 25 \\
6 \cdot 6 \\
7 \cdot 6\end{array}$ & $\begin{array}{l}F \\
F \\
F \\
F \\
F\end{array}$ & $\begin{array}{l}39 \\
42 \\
38 \\
40 \\
36\end{array}$ & $\begin{array}{l}2100 \\
1800 \\
2040 \\
3030 \\
2150\end{array}$ & 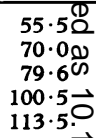 \\
\hline
\end{tabular}

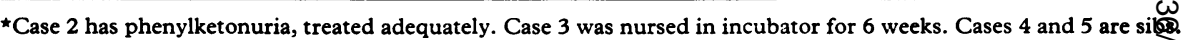

+ , present; -, not present.

TAB: $\vec{G} \mathrm{E}$

Immunoreactive growth hormone $(\mathrm{ng} / \mathrm{ml})$ response to insulin-induced hypoglycaemia

\begin{tabular}{|c|c|c|c|c|c|c|c|}
\hline \multirow{2}{*}{$\begin{array}{l}\text { Case } \\
\text { no. }\end{array}$} & \multirow[b]{2}{*}{ Sex } & \multirow[b]{2}{*}{$\begin{array}{c}\text { Age } \\
\text { (year) }\end{array}$} & & & & \multicolumn{2}{|c|}{ Insulin-induced trypo } \\
\hline & & & -30 & 0 & 15 & 30 & $45 \frac{\mathbb{D}}{0}$ \\
\hline $\begin{array}{l}1 \\
1 \\
3 \\
4 \\
5\end{array}$ & $\begin{array}{l}\mathbf{F} \\
\mathbf{F} \\
\mathbf{F} \\
\mathbf{F} \\
\mathbf{F}\end{array}$ & $\begin{array}{l}0 \cdot 7 \\
2 \cdot 0 \\
2 \cdot 3 \\
6 \cdot 5 \\
7 \cdot 6\end{array}$ & $\begin{array}{l}- \\
3 \cdot 6 \\
3 \cdot 0 \\
- \\
-\end{array}$ & $\begin{array}{r}23 \cdot 2 \\
4 \cdot 0 \\
2 \cdot 0 \\
17 \cdot 1 \\
2 \cdot 8\end{array}$ & $\begin{array}{r}5 \cdot 9 \\
2 \cdot 5 \\
9 \cdot 6 \\
2 \cdot 8 \\
35 \cdot 0\end{array}$ & $\begin{array}{r}33 \cdot 5 \\
26 \cdot 3 \\
147 \cdot 0 \\
3 \cdot 9 \\
50 \cdot 0\end{array}$ & 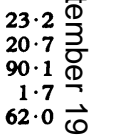 \\
\hline
\end{tabular}
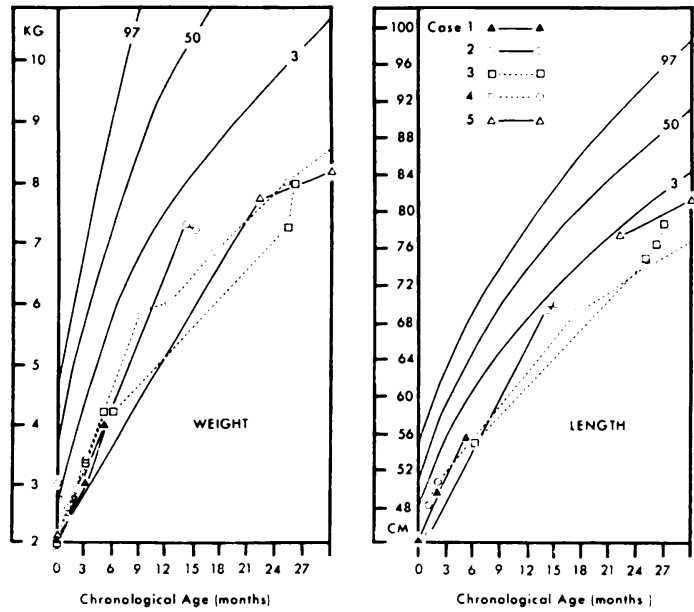

Fig. 1.-Growth from birth to 2 years in the 5 children with fetal alcohol syndrome.

The serum levels of somatomedin showed a potency of 1.20 and 1.46 greater than normal pooled serum on samples with raised $\mathrm{GH}$ of $150 \mathrm{ng} / \mathrm{ml}$ and $147 \mathrm{ng} / \mathrm{ml}$ in Cases 2 and 3 respectively.

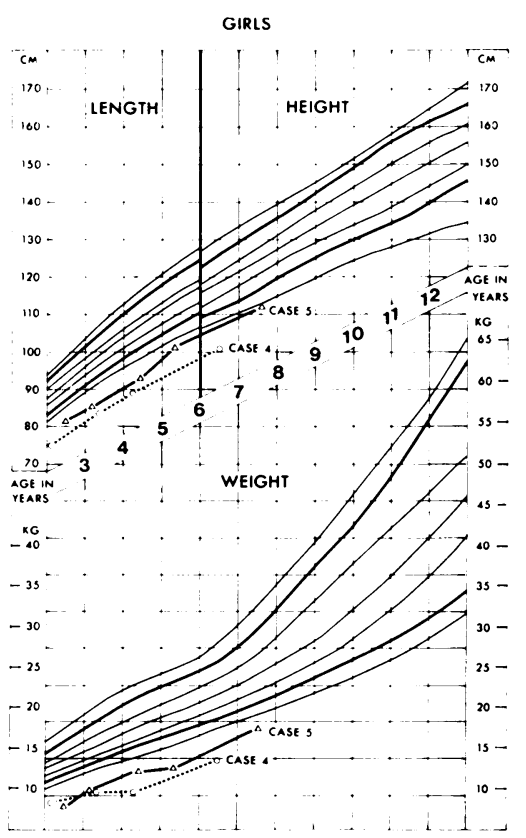

Fig. 2.-Growth of Cases 4 and 5 after age 2 years. 
I

with fetal alcohol syndrome

\begin{tabular}{c|c|c|c|c|c|c}
\hline $\begin{array}{c}\text { Weight } \\
\text { (kg) }\end{array}$ & $\begin{array}{c}\text { Head } \\
\text { circumference } \\
\text { (cm) }\end{array}$ & $\begin{array}{c}\text { Delayed } \\
\text { behavioural } \\
\text { development }\end{array}$ & $\begin{array}{c}\text { Short } \\
\text { palpebral } \\
\text { fissures }\end{array}$ & $\begin{array}{c}\text { Craniofacial } \\
\text { abnormalities }\end{array}$ & $\begin{array}{c}\text { Joint } \\
\text { anomalies }\end{array}$ & $\begin{array}{c}\text { Cardiac } \\
\text { anomalies }\end{array}$ \\
\hline 4.0 & $29 \cdot 0$ & + & + & + & + & + \\
$7 \cdot 2$ & $42 \cdot 0$ & + & + & - & + & + \\
$8 \cdot 0$ & $36 \cdot 0$ & + & + & + & + & + \\
$13 \cdot 4$ & $46 \cdot 0$ & + & + & + & + & \\
$17 \cdot 2$ & $47 \cdot 5$ & + & + & + & + \\
\hline
\end{tabular}

II

arginine infusion in 5 children with fetal alcohol syndrome (time interval in minutes)

\begin{tabular}{|c|c|c|c|c|c|c|}
\hline \multicolumn{3}{|c|}{ zlycaemia (min) } & \multicolumn{4}{|c|}{ Arginine infusion (min) } \\
\hline 60 & 90 & 120 & -30 & 0 & 30 & 60 \\
\hline $\begin{array}{r}7 \cdot 2 \\
9 \cdot 1 \\
41 \cdot 8 \\
1 \cdot 8 \\
40 \cdot 0\end{array}$ & $\begin{array}{r}5 \cdot 0 \\
3 \cdot 2 \\
16 \cdot 0 \\
1 \cdot 4 \\
12 \cdot 0\end{array}$ & $\begin{array}{l}1 \cdot 5 \\
1 \cdot 5 \\
8 \cdot 0 \\
2 \cdot 2 \\
1 \cdot 8\end{array}$ & $\begin{array}{l}1 \cdot 5 \\
3 \cdot 0 \\
3 \cdot 0 \\
- \\
-\end{array}$ & $\begin{array}{r}150 \cdot 0 \\
28 \cdot 5 \\
4 \cdot 2 \\
7 \cdot 2 \\
2 \cdot 9\end{array}$ & $\begin{array}{r}26 \cdot 8 \\
3 \cdot 3 \\
11 \cdot 5 \\
17 \cdot 0 \\
40 \cdot 1\end{array}$ & $\begin{array}{r}39 \cdot 8 \\
7 \cdot 7 \\
3 \cdot 7 \\
45 \cdot 6 \\
55 \cdot 0\end{array}$ \\
\hline
\end{tabular}

\section{Discussion}

The finding of raised levels of $\mathrm{GH}$ in some of our patients in the presence of growth failure was unexpected. This unusual combination has been observed in some patients with hypothalamic tumour (Kerpel-Fronius, Gaćs, and Hervei 1973), in cases of severe malnutrition (Alvarez et al., 1972) and in Laron syndrome (Laron, Pertzeland, and Karp, 1968). The reason for the poor linear growth associated with adequate GH level is not apparent. In the 2 patients in whom the serum somatomedin level was estimated this was normal, so that somatomedin deficiency would not have accounted for the poor linear growth. It is unlikely that the immunoreactive $\mathrm{GH}$ is biologically inactive since somatomedin is produced under the influence of $\mathrm{GH}$ acting on the liver, the presumed site of action of this hormone. The inadequate linear growth may be due to a peripheral tissue insensitivity to $G H$ as has been postulated in Laron syndrome and in pygmies (Rimoin et al., 1969).

Raised serum level of immunoreactive $\mathrm{GH}$ and also other hormones has been shown after the ingestion of alcohol in human experiments (Fabre, Howard, and Farmer, 1972; Bellet et al., 1971), and the effect has been observed to be transient. It is of interest to note that a raised $\mathrm{GH}$ response to one stimulus is not necessarily followed by a similar response to another stimulus in the same subject. For example, Case 3 had a normal response to arginine, and yet after insulin the GH level increased to $147 \mathrm{ng} / \mathrm{ml}$. Similarly, the fasting basal $\mathrm{GH}$ value varied unpredictably as is shown by a comparison of the ' 0 ' values during arginine or insulin tests. Whether the observed rise in $\mathrm{GH}$ after the stimulatory tests in our patients was a chance or sporadic finding, or whether they imply some alteration in the GH status of these patient remains undecided.

We thank Drs. J. C. Naylor, M. Stevens, H. G. Dunn, and $B$. Tischler for permission to include their patients in the study, and Dr. D. Hardwick for technical assistance.

\section{REFERENCES}

Alvarez, L. C., Dimas, C. O., Castro, A., Rossman, L. G., Vanderlaan, E. F., and Vanderlaan W. P. (1972). Growth hormone in malnutrition. fournal of Clinical Endocrinology and Metabolism, 34, 400.

Bala, R. M., Hankins, C., and Smith, G. R. (1975). A Somatomedin assay using normal rabbit cartilage in clinical studies. Canadian fournal of Physiology and Pharmacology, 53, 403.

Bellet, S., Yoshimine, N., DeCastro, O. A. P., Roman, L., Parmar, S. S., and Sandberg, H. (1971). Effects of alcohol ingestion on growth hormone levels: their relation to 11-hydroxycorticoid levels and serum FFA. Metabolism, 20, 762. 
Criteria Committee, National Council on Alcoholism. (1972) Criteria for the diagnosis of alcoholism. Annals of Internal Medicine, 77, 249.

Fabre, L. F., Howard, P. Y., and Farmer, R. W. (1972). Endocrine abnormalities in male alcoholic subjects. Texas Medicine News, 68, 88.

Jones, K. L., and Smith, D. W. (1973). Recognition of the fetal alcohol syndrome in early infancy. Lancet, 2, 999.

Jones, K. L., Smith, D. W., Ulleland, C. N., and Streissguth, A. P. (1973). Pattern of malformation in offspring of chronic alcoholic mothers. Lancet, $1,1267$.

Kerpel-Fronius, E., Gacs, G., and Hervei, C. (1973). Growth hormone in marasmus due to cerebral disease. American Fournal of Diseases of Children, 126, 303.

Laron, Z., Pertzelan, A., and Karp, M. (1968). Pituitary dwarfism with high serum levels of growth hormone. Israel fournal of Medical Sciences, 4, 883.

Pozsonyi, J., and Friesen, H. G. (1971). Growth hormone investigation in patients with mental dysfunction. Canadian Medical Association fournal, 104, 26.

Rimoin, D. I., Merimee, T. J., Rabinowitz, D., Cavilli-Sforza, L. L., and McKusick, V. A. (1969). Peripheral subresponsiveness to human growth hormone in the African pygmies. New England fournal of Medicine, 281, 1383.

Correspondence to Dr. W. J. Tze, Children's Hospital, 250 West 59th Avenue, Vancouver, B.C. V5X 1 X2 Canada. 